\title{
KONVERGENSI IFRSDAN PELUANG PRAKTIK MANAJEMEN LABA DI INDONESIA: SEBUAH LITERATUR REVIEW
}

\author{
Arief Hidayatullah Khamainy \\ Fakultas Ekonomi dan Bisnis, Universitas Wiraraja, Sumenep (Indonesia) \\ ariefkhamainy@wiraraja.ac.id
}

\begin{abstract}
Earnings management practices result in the fact that the economic conditions in the company's financial statements are not actually presented so that the profits that are expected to provide information to support decision making are doubtful. The existence of IFRS encourages managers to perform high-quality financial reporting, resulting in high-quality earnings as well. This paper aims to analyze the opportunities for earnings management practices after IFRS convergence in Indonesia. The secondary data used in this literature study were obtained from empirical studies on the convergence of IFRS and earnings management in Indonesia. The results of the analysis show that the opportunity for earnings management practices will exist, both after the convergence of IFRS, so the importance of supervision carried out by investors to obtain reliable financial information as a basis for decision making.
\end{abstract}

Keywords :IFRS Convergence, Earnings Management.

\section{PENDAHULUAN}

Setelah berakhirnya perang dunia kedua, pertumbuhan besar dalam perdagangan internasional dan adanya bentuk saling ketergantungan lainnya diantara berbagai negara memiliki signifikansi yang sangat besar bagi banyak aspek kehidupan. Secara umum, perkembangan ini memiliki efek homogenisasi pada banyak kebiasaan, praktik, dan kelembagaan. Dalam bisnis, beberapa kondisi tertentu menyebabkan keinginan untuk menyelaraskan atau menyatukan standar akuntansi antar bangsa. Menurut Van Der Tas(1992); Harmonisasi mengacu pada tingkat koordinasi atau kesamaan diantara berbagai perangkat standar akuntansi nasional dan metode serta format pelaporan keuangan. Harmonisasi dibagi menjadi dua aspek: (1) Harmonisasi Material (disebut juga harmonisasi de facto) mengacu pada harmonisasi antara praktik akuntansi perusahaan yang berbeda baik yang berasal dari peraturan maupun tidak, dan (2) Harmonisasi Formal (disebut juga harmonisasi de jure) mengacu pada proses atau tingkat harmonisasi yang ada diantara aturan atau regulasi akuntansi dari berbagai negara atau kelompok.

Menurut Wolk et al., (2017) Perusahaan multinasional merupakan salah satu faktor kuat yang mendorong adanya harmonisasi. Dengan adanya kesamaan umum standar dan prosedur akuntansi menfasilitasi koordinasi di antara bagian-bagian perusahaan multinasional.Secara khusus, pelaporan keuangan konsolidasi tentu lebih mudah 
jika aturan akuntansi yang berlaku di berbagai bagian perusahaan multinasional lebih konsisten. Pelengkap kebangkitan perusahaan multinasional adalah internasionalisasi yang terjadi dalam profesi akuntan publik. Banyak perusahaan memiliki keahlian dan praktik di seluruh dunia, sehingga dengan adanya harmonisasi akan semakin menfasilitasi fungsi audit profesi akuntan publik tersebut.

Setelah terjadinya perang dunia kedua yang menghancurkan, yang sebagian besar terjadi di Eropa Barat, berbagai upaya dilakukan untuk mengintegrasikan negara-negara di kawasan ini baik secara ekonomi maupun secara politik, sehingga terbentuklah Uni Eropa pada tahun 1967. Dengan terbentuknya Uni Eropa ini dorongan untuk mengintegrasikan negara-negara anggotanya semakin kuat, salah satunya yaitu dengan harmonisasi standar akuntansi negara anggotanya, sehingga pada akhirnya anggota Uni Eropa ini mengadopsi standar IASB. Jika dilihat dari sudut pandang harmonisasi, IASB mirip dengan US GAAP. Namun, pada akhirnya harmonisasi disebut dengan konvergensi. Tahun 2002, dengan adanya perjanjian Norwalk IASB dan FASB menjadi awal dalam perkembangan standar akuntansi yang dapat digunakan secara luas, keduanya berkomitmen untuk melakukan konvergensi IFRS dan US GAAP.

Tuntutan untuk mempersiapkan diri dalam melakukan pencatatan dan pelaporan keuangan dengan mengadopsi secara penuh standar akuntansi IFRS semakin tinggi, utamanya setelah terjadinya perjanjian Norwalk pada tahun 2002(Cahyonowati \& Ratmono, 2013). Tidak terkecuali di Indonesia, menurut Firmansyah \& Irawan (2018) perusahaan yang sudah terdaftar di Bursa Efek Indonesia (BEI) per 1 Januari 2012 diwajibkan untuk menggunakan standar akuntansi keuangan berbasis IFRS agar kebutuhan akan standar akuntansi yang berkualitas tinggi dapat tercapai, standar akuntansi berkualitas tinggi ini adalah standar yang secara umum diterima sebagai aturan baku, konsisten, bisa dibandingkan, dapat dipertanggungjawabkan, relevan, dan dapat diandalkan yang berguna bagi para pengguna laporan keuangan dalam pengambilan keputusan.

Manfaat pengadopsian IFRS
secara umum diantaranya yaitu
memudahkan pemahaman atas laporan
keuangan dengan penggunaan Standar
Akuntansi Keuangan yang dikenal
secara internasional (enhance compara-
bility), meningkatkan arus investasi
global melalui transparansi, menurunkan
biaya modal dengan membuka peluang


fund rising melalui pasar modal secara global, menciptakan efisiensi penyusunan laporan keuangan, meningkatkan kualitas laporan keuangan dengan cara mengurangi kesempatan untuk melakukan earnings management (Martani, 2014). Peningkatan kualitas dari laporan keuangan di suatu perusahaan dapat dilihat dari perilaku praktik manajemen laba. Menurut Barth et al., (2008) laporan keuangan yang berkualitas tinggi ditandai oleh manajemen laba yang kecil, pengakuan rugi tepat waktu dan memiliki relevansi nilai yang tinggi sehingga dibutuhkan standar keuangan yang bisa mengurangi praktik manajemen laba, yang dapat meningkatkan kualitas laporan keuangan dan berdampak pada meningkatnya nilai perusahaan.

Adanya praktik manajemen laba mangakibatkan fakta tentang kondisi ekonomis dalam laporan keuangan perusahaan tidak disajikan sebenarnya sehingga laba yang diharapkan dapat memberikan informasi untuk mendukung pengambilan keputusan menjadi diragukan. Aryani (2011) menyatakan upaya menyelewengkan informasi dilakukan manajer dengan mempermainkan komponen-komponen dalam laporan keuangan, baik dengan mempermainkan besar kecilnya laba, maupun menyembunyikan atau menunda pengungkapan komponen tertentu. Upaya ini dilakukan manajer tanpa harus melanggar standar akuntansi yang selama ini digunakan secara umum, dengan memanfaatkan berbagai metode dan prosedur yang terdapat dalam standar akuntansi, sehingga standar akuntansi seolah-olah memberi kesempatan perusahaan untuk mengatur dan mengelola laba perusahaan. Proses penyusunan laporan keuangan yang berbasis akrual melibatkan banyak estimasi dan taksiran, misalnya, estimasi umur aktiva tetap dan taksiran besarnya nilai residu aktiva tetap dalam menentukan besarnya biaya depresiasi suatu aktiva tetap (Setyaningrum, 2008).

$$
\text { Banyak kasus manipulasi }
$$
laporan keuangan yang terdeteksi di Indonesia oleh BAPEPAM, misalnya kasus Kimia Farma yang menaikkan laba bersihnya yang bertujuan untuk menarik investor. Kemudian kasus lainnya di Amerika yaitu Enron yang memanipulasi laporan keuangannya yang mana perusahaan menyatakan mendapat laba, yang mana sebenarnya mengalami kerugian. Sehingga banyak stakeholders yang merasa dirugikan akibat harga saham yang tinggi pada saat manipulasi manajemen laba terjadi, kemudian ditahun berikutnya mengalami penurunan harga saham yang signifikan dan Enron pun menyatakan kebangkrutannya (Prima, 2013). 
Salah satu kasus yang terjadi di Indonesia yaitu pada saat pengakuisisian PT. Akira Indonesia dan PT. TT Indonesia, direktur utama PT Agis menyatakan pendapatan kedua perusahaan tersebut mencapai $\mathrm{Rp} 800$ miliar, namun didasarkan laporan keuangan kedua perusahaan per 31 maret 2007, total pendapatan hanya senilai Rp 466,8M. Dalam laporan laba rugi konsolidasi, terdapat pendapatan bersih Rp 29,4 miliar yang dianggap tidak wajar. Dan pada kejadian PT. Invisi Infracom, pihak BEI menemukan penyalahsajian item pembayaran kas kepada karyawan dan penerimaan bersih utang pihak berelasi dalam laporan arus kas periode September 2014. Pada kuartal pertama 2014, pembayaran gaji pada karyawan sebesar Rp 1,9 triliun. Namun, pada kuartal ketiga 2014 angka pembayaran gaji pada karyawan turun menjadi Rp 59 miliar. Dalam revisi laporan keuangannya ditemukan beberapa nilai pada laporan keuangan mengalami perubahan nilai, dengan contoh penurunan nilai aset tetap menjadi Rp 1,16 triliun dan setelah direvisi, sebelumnya diakui senilai $\mathrm{Rp}$ 1,45 Trilun. Sehingga pada tahun 2017, pihak BEI memutuskan untuk menghapus pencatatan efek PT. INVS dari BEI (Satria \& Jeni, 2020).

Tingginya manajemen laba yang dilakukan oleh perusahaan maka nantinya akan berhubungan erat dengan tingkat kualitas laba yang rendah dan manajer melakukan manajemen laba untuk menjamin laba yang berkualitas tinggi. Menurut Satria \& Jeni (2020) Investor menyalurkan dana melalui pasar modal return yang disebabkan karena ada perasaan aman akan melakukan kegiatan investasi dan tingkatan hasil yang diperoleh dari kegiatan investasi tersebut. Return memungkinkan investor untuk membandingkan keuntungan aktual ataupun keuntungan yang diharapkan yang disediakan oleh berbagai investasi pada tingkat pengembalian yang diinginkan. Di sisi lain, return memiliki peran yang sangat signifikan dalam menentukan nilai dari investasi. Salah satu penyebab terjadi tindakan manajemen laba adalah leverage, karena dengan adanya leverage hal itu dapat menunjukan seberapa besar aset perusahaan yang dibiayai oleh hutang. Hal ini dikarenakan perusahaan yang memiliki tingkat leverage yang tinggi akibat total hutang terhadap total aset akan menghadapi resiko tidak mampu memenuhi kewajibannya membayar hutang perusahaan yang tingkat pertumbuhan penjualannya tinggi, akan cenderung menggunakan utang dalam struktur modalnya.

$$
\text { Berdasarkan latar belakang }
$$
tersebut, penelitian ini bertujuan untuk 
menganalisis peluang praktik

manajemen laba setelah adanya

konvergensi International Financial

Reposrting Standarads (IFRS) di

Indonesia.

\section{LANDASAN TEORI}

Teori Agency

Agency theory merupakan teori yang dikemukakan olehJensen \& Meckling (1976) yang menjelaskan hubungan keaganenan antara principal dengan agen, masalah keagenan muncul ketika principal (pemilik perusahaan) dan manajemen (agen) keduanya memiliki perbedaan kepentingan yang disebut dengan agency problem, permasalahan muncul ketika agency problem tersebut memunculkan biaya keagenan atau agency cost, agency cost merupakan sebuah biaya yang dikeluarkan oleh perusahaan untuk memastikan bahwa agen sudah bertindak sesuai dengan kepentingan principal, agen tentunya tidak menyukai adanya agency cost dikarenakan biaya tersebut akan menurunkan kinerja meningkatkan laba perusahaan. Salah satu biaya yang harus dikeluarkan adalah biaya pengawasan, baik pengawasan internal maupun pengawasan eksternal melalui audit eksternal.

Adanya perbedaan kepentingan dengan berlandaskan tingkat kemakmuran membuat muncul adanya dorongan kepada agen untuk bisa mencapai atau memenuhi kepentingan pribadinya yang dibuat seolah-olah untuk memenuhi kepentingan principal.

Adanya dorongan pribadi ini bisa meyebabkan kurang berkualitasnya laba yang disajikan oleh manajemen, sehingga laba yang berkualitas dapat dilihat dari kualitas akrual yang tinggi dan persistensi laba yang berkelanjutan.

Hal ini berarti principal kurang mengetahui kualitas laba yang sebenarnya. Kualitas laba juga bisa dipengaruhi oleh kualitas standar leporan keuangan, jenis standar laporan keuangan yang satu dengan yang lainnya memiliki perbedaan dalampelaksanaannya atau unsur standar yang diterapkan. Melalui standar laporan keuangan yang berbeda, agen dapat membentuk kualitas akrual dan persistensi laba yang berbeda dengan memanfaatkan peluang dari standar laporan keuangan yang diadopsi.

METODE

Data yang digunakan dalam penulisan makalah ini merupakan data sekunder, yaitu data yang berisi penelitian-penelitian empiris terdahulu yang telah dilakukan sebelumnya menggunakan mesin pencari Google Scholar dengan menggunakan kata kunci "Konvergensi IFRS dan Manajemen Laba". Artikel ini ditulis dengan menggunakan studi literatur dari hasil penelitian empiris sebelumnya. 
Aspek yang digunakan untuk mengidentifikasi apakah dengan adanya konvergensi IFRS akan memunculkan peluang praktik manajemen laba yang semakin besar atau sebaliknya.

\section{HASIL PENELITIAN}

Adopsi International Financial Reposting Standards (IFRS)

Tonggak sejarah munculnya standar akuntansi di Indonesia diawali dari munculnya pergerakan pasar saham diIndonesia yaitu tahun 1973, pada masa itu merupakan pertama kalinya IAI melakukan kondisifikasi prinsip dan standar akuntansi yang berlaku di Indonesia dalam suatu buku yang disebut "Prinsip Akuntansi Indonesia". Dari tahun ke tahun semakin berkembang sejalan dengan perkembangan dunia bisnis di Indonesia.

Dari serangkaian proses harmonisasi standar dengan standar interna- sional, konvergensi terhadap IFRS merupakan hal baru dan menjadi pencetus munculnya paradigma baru perkembangan standar di Indonesia.

Lebih lanjut mengenai tahapan pengadopsian IFRS di Indonesia dapat digambarkan seperti gambar 1 .

Pada Gambar 1, tahap adopsi IFRS di Indonesia dimulai pada tahun 2008-2010, pada tahapan penyusun standar di Indonesia masih dalam tahap persiapan infrastruktur yang diperlukan, kemudia mengevaluasi dan mengelola dampak dari pengadopsian IFRS. Tahap persiapan akhir terjadi pada tahun 2011, pada tahun ini beberapa infrastruktur yang diperlukan telah dirampungkan kemudian penerapan secara bertahap PSAK berbasis IFRS yang kemudian mulai diimplementasikan pada tahun 2012.

Gambar 1

Tahap Pengadopsian IFRS di Indonesia

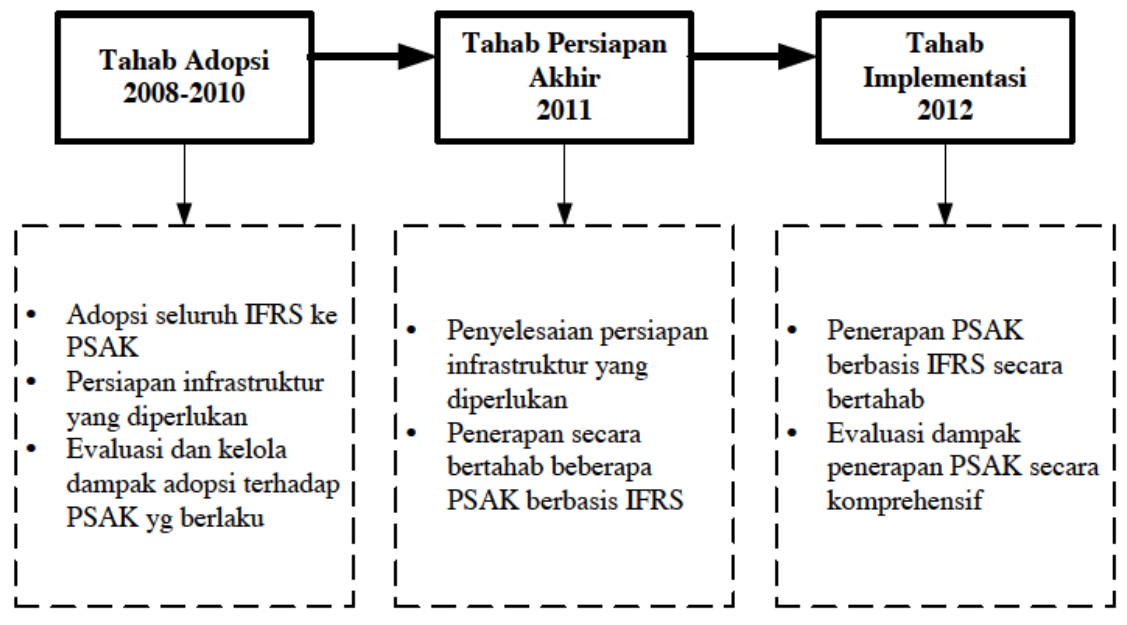

Sumber :Lestari, 2013) 
Perbedaan IFRS dan US GAAP

Nilai wajar

Sebelum digunakan IFRS akuntansi menggunakan historical cost untuk pengukuran transaksinya.Historical cost merupakan jumlah kas atau yang disetarakan dengan kas dan sudah ditransaksikan atau nilai wajar imbalan lain yang diserahkan untuk memperoleh aset pada saat perolehan atau konstruksi, atau jika dapat diterapkan jumlah yang dapat diatri-busikan langsung ke aset pada saat pertama kali diakui sesuai dengan persyaratan tertentu didalam PSAK lain (PSAK 19, revisi 2009).

Kelebihan dari metode historical cost yaitu terletak pada sifatnya yang lebih veriable dan objektif karena data yang disajikan berdasarkan transaksi yang sesungguhnya dan sudah terjadi, sedangkan kekurangan dari historical cost yaitu kurang tercerminnya kondisi perusahaan yang sesungguhnya, namun demikian pihak manajemen bisa memanfaatkan kelemahan historical cost untuk melakukan manajemen laba, misalnya pada saat kinerja perusahaan sedang buruk apabila nilai wajar aset pada tanggal pelaporan lebih besar dari nilai tercatatnya maka pihak manajemen akan menjual aset tersebut sehingga ada keuntungan yang terjadi diakui di dalam laporan laba rugi.
Standar IFRS lebih kepada penggunaan nilai wajar, terutama properti investasi, beberapa aset tak berwujud, aset keuangan, dan aset biologis. Dengan demikian maka diperlukan sumber daya yang kompeten untuk menghitung nilai wajar atau bahkan perlu menyewa jasa konsultan penilai terutama untuk aset-aset yang tidak memiliki nilai pasar aktif. Menurut IAI (2009) Nilai wajar (fair value) adalah suatu jumlah yang dapat digunakan sebagai dasar pertukaran aset atau penyelesaian kewajiban antara pihak yang paham (knowledgeable) dan berkeinginan untuk melakukan transaksi wajar (arm's length transaction). Keuntungan digunakan nilai wajar adalah bahwa pos-pos aset dan liabilitas yang dimiliki lebih mencerminkan nilai yang sebenarnya pada saat tanggal laporan keuangan.

Namun terdapat argumen yang menolak penggunaan nilai wajar yang menyatakan bahwa penggunaan nilai wajar menyebabkan volatilitas dalam laporan keuangan dan mengurangi prediksi dari laba. Jika penggunaan nilai wajar menyebabkan volatilitas yang tinggi hal tersebut sebenarnya hanya mengungkapkan realitas ekonomi yang sebenarnya (Siregar, 2010). Dengan demikian peralihan dari biaya historis ke nilai wajar diharapkan akan mengurangi 


\section{FAKULTAS EKONOMI DAN BISNIS UNIVERSITAS WIRARAJA - MADURA}

manajemen laba yang dilakukan oleh perusahaan.

\section{Principal based}

Sebelum konvergensi ke IFRS, standar akuntansi di Indonesia menggunakan US GAAP yang dirumuskan oleh FASB. US GAAP merupakan standar yang rules based (berbasis aturan). Standar yang berbasis aturan akan meningkatkan konsistensi dan keterbandingan antar perusahaan dan antar waktu, namun di sisi lain mungkin kurang relevan karena ketidakmampuan standar merefleksi kejadian ekonomi entitas yang berbeda antar perusahaan dan antar waktu.

Standar berbasis aturan juga akan mengakibatkan munculnya standarstandar akuntansi untuk industri tertentu misalnya akuntansi penyelenggaraan jalan tol, akuntansi koperasi, akuntansi kehutanan, akuntansi perbankan.Padahal secara prinsip terdapat ke-samaan untuk standar akuntansi tersebut dari sisi pengakuan pendapatan dan pengakuan aset.

Semakin banyak aturan, maka aturan tersebut akan semakin memiliki banyak celah untuk dilanggar. Hal ini mengakibatkan aturan akan semakin banyak untuk menutup celah-celah yang lain. Standar yang detail juga menyediakan insentif bagi manajemen untuk mengatur transaksi sesuai hasil yang diharapkan berdasarkan aturan dalam standar. Auditorpun menjadi lebih sulit untuk menolak manipulasi yang dilakukan oleh manajemen ketika ada aturan detail yang menjustifikasinya (Cahyati, 2011).

Berbeda dengan US GAAP yang berbasis aturan standar akuntansi IFRS berbasis prinsip. Pengaturan pada tingkat prinsip akan meliputi segala hal dibawahnya.Namunkelemahannya, akan dibutuhkan penalaran, judgement, dan pemahaman yang cukup mendalam dari pembaca aturan dalam mene-rapkannya. Standar semacam ini konsisten dengan tujuan pelaporan keuangan untuk dapat menggambarkan kejadian yang sesungguhnya di perusahaan. Standar berbasis prinsip memberi keunggulan dalam hal memungkinkan manajer memilih perla-kuan akuntansi yang merefleksikan transaksi atau kejadian ekonomi yang mendasarinya, meskipun hal sebaliknya dapat terjadi. Standar berbasis prinsip memungkinkan manajer, anggota komite audit, dan auditor menerapkan judgment profesionalnya untuk lebih fokus pada merefleksi kejadian atau transaksi ekonomi secara substansial, tidak sekedar melaporkan transaksi atau kejadian ekonomi sesuai dengan standar. 
Persyaratan pengungkapan yang lebih banyak dan lebih rinci

IFRS mensyaratkan pengungkapan berbagai informasi tentang risiko baik kualitatif maupun kuantitatif. Pengungkapan dalam laporan keuangan harus sejalan dengan data/informasi yang dipakai untuk pengambilan keputusan yang diambil oleh manajemen.

Tingkat pengungkapan yang makin mendekati pengungkapan penuh (full disclosure) akan mengurangi tingkat asimetri informasi (ketidakseimbangan informasi) ketidakseimbangan informasi antara manajer dengan pihak pengguna laporan keuangan.

Asimetri informasi adalah kondisi dimana manajer mempunyai informasi superior dibandingkan dengan pihak lain. Oleh karena itu manajer akan melakukan dysfunctional behavior dengan melakukan manajemen laba terutama jika informasi tersebut terkait dengan pengukuran kinerja manajer. Jadi, dapat disimpulkan kondisi informasi asimetri inilah yang merupakan kondisi yang dibutuhkan untuk dilakukannya manajemen laba. Dengan kata lain tingkat pengungkapan memiliki hubungan negatif dengan manajemen laba hal ini sejalan dengan penelitian yang dilakukan oleh Siregar dan Bachtiar (2003) menemukan bahwa perusahaan yang melakukan manajemen laba cenderung mengungkapkan informasi lebih sedikit dalam laporan keuangannya agar tidak terdeteksi. Perusahaan dengan tingkat pengungkapan minimal cenderung melakukan manajemen laba dan sebaliknya.

\section{Manajemen Laba}

\section{Definisi Manajemen Laba}

Teori keagenan atau teori agency merupakan teori yang digunakan dalam pendekatan konsep manajemen laba. Teori agency merupakan teori yang menggambarkan adanya kepentingan antara kedua pihak yaitu principal dan agent, yang dimaksud dengan principal disini yaitu pemegang saham atau pemilik perusahaan sedangkan yang dimaksud agent yaitu agen dari perusahaan atau manajemen. Menurut Jackson et al. (2013) kedua pihak ini memiliki kepentingannya masingmasing sehing-ga mereka akan lebih memilih untuk mendahulukan kepentingan diri sendiri, sehingga timbul konflik kepentingan antara agent dengan principal.

Manajemen sebagai agen
memiliki kepentingan bagaimana
caranya agar dia dapat melaporkan laba
perusahaan dengan baik kepada
principal, kepentingannya tentunya dari
sisi agent seperti penilaian kinerja
sehingga agent dinilai baik dan
mendapatkan bonus yang dijanjikan oleh
principal. Adanya kelonggaran peng-


gunaan metode dan prosedur akuntansi menurut Cahyati (2011) dapat menjadi celah bagi pihak menajemen untuk mengintervensi laba baik itu menaikkan laba atau menurunkan laba karena adanya keleluasaan pihak manajemen untuk memilih metode akuntansi sesuai dengan standar akuntansi yang berlaku, intervensi inilah yang disebut dengan manajemen laba.

\section{Motivasi Manajemen Laba}

Laba merupakan salah satu informasi yang sangat diperlukan oleh pengguna laporan keuangan dalam pengambilan keputusan utamanya investor dalam kepentingan keputusan investasi dan kreditor dengan kepentingannya dalam pemberian kredit. Dengan sangat sensitifnya informasi laba tersebut sehingga mendorong manajemen untuk melakukan manajemen laba (Cahyati, 2011). Ada beberapa motivasi yang mendorong manajemen tetap melakukan manajemen laba menurut Pamudhi dan Trihartati (2010), yaitu sebagai berikut:

a) Bonus plan hypothesis, dimana laba juga sebagai dasar dalam pemberian bonus kepada karyawan. Misalnya pada saat keuntungan dijadikan patokan dalam pemberian bonus, maka akan menciptakan dorongan kepada para manajer untuk mengatur data keuangan agar dapat menerima bonus seperti yang diinginkan.

b) Debt (equity) hypothesis, menegaskan bahwa perusahaan dengan debt to equity ratio lebih besar, cenderung untuk memilih prosedur akuntansi yang dapat menaikkan labanya.

c) Political cost hypothesis, perusahaan cenderung memilih metode akuntansi yang dapat menurunkan laba bersih yang dilaporkan. Manajamen laba yang dilakukan manajer akan menurunkan kualitas laba. Manajemen laba akan membuat kemampuan laba untuk memprediksi laba masa depan menjadi berkurang.

\section{Teknik Manajemen laba}

Teknik dan pola manajemen laba menurut Setiawati dan Na'im (2000) dalam Pamudji \& Trihartati (2010) dapat dilakukan dengan cara sebagai berikut:

a) Memanfaatkan peluang untuk membuat estimasi akuntansi Manajemen dapat mempengaruhi laba melalui perkiraan terhadap estimasi akuntansi antara lain estimasi tingkat piutang tak tertagih, estimasi kurun waktu depresiasi aset tetap atau amortisasi aset tidak berwujud, estimasi biaya garansi, dll.

b) Mengubah metode akuntansi manajemen laba dapat dilakukan dengan mengubah metode akuntansi yang 
digunakan untuk mencatat suatu transaksi. Contoh mengubah depresiasi aset tetap dari metode jumlah angka tahun ke metode garis lurus.

c) Menggeser periode biaya atau pendapatan Manajemen laba dapat dilakukan dengan menggeser periode atau pendapatan. Contohnya dengan mempercepat atau menunda pengeluaran untuk penelitian sampai pada periode akuntansi periode berikutnya, mempercepat atau menunda pengeluaran promosi sampai periode berikutnya, mempercepat atau menunda pengiriman produk ke pelanggan, mengatur penjualan aset tetap perusahaan.

\section{Implikasi Manajemen laba}

Disfunctional behavior pihak manajemen dengan melakukan manajemen laba akan menyebabkan beberapa dampak bagi pengguna laporan keuangan eksternal maupun internal pertama bagi investor manajemen laba menyebabkan pengungkapan informasi mengenai penghasilan bersih atau laba menjadi menyesatkan, manajemen laba dapat merugikan investor, karena akibat dari tidak akurat dan tidak cukupnya pengungkapan atas laba, investor tidak dapat mengevaluasi return, dan resiko yang timbul atas portofolionya (Cahyati, 2011).
Kedua bagi Manajer sendiri, akan menanggung akibat dari manajemen laba yaitu berupa kemungkinan kesulitan keuangan atau kebangkrutan masa depan (Pamudji \& Trihartati, 2010).

Ketiga bagi regulator menanggung implikasi berupa hilangnya integritas dan kredibilitas karena regulasinya mudah dipermainkan (Pamudji \& Trihartati, 2010)mengingat bahwa fungsi standar akuntansi secara garis besar adalah melaporkan informasi yang relevan, dapat diandalkan (reliable), dapat dipahami (understable) dan dapat diperbandingkan (comparable) kepada pemangku kepentingan (Kartikahadi, 2010), maka manajemen laba yang dilakukan oleh pihak manajemen dapat mengurangi keandalan dari laporan keuangan perusahaan. Keempat kreditur harus menanggung implikasi berupa hilangnya kesempatan memperoleh return dan dana yang dipinjamkan kepada perusahaan yang bersangkutan (Pamudji \& Trihartati, 2010).

\section{Penelitian Empiris Konvergensi IFRS} dan Manajemen Laba

Ada banyak penelitian empiris yang telah dilakukan kaitannya dengan konvergensi IFRS dan manajemen laba di Indonesia di antaranya adalah penelitian yang dilakukan oleh Kusumawardani \& Dewi, (2017) penelitian ini bertujuan untuk menganalisis 
implikasi manajemen laba terhadap konvergensi IFRS di Indonesia. Penelitian ini menggunakan perusahaan manufaktur yang terdaftar di Bursa Efek Indonesia (BEI) sebagai objek penelitiannya. Hasilnya menunjukkan bahwa tidak ada pengaruhnya konvergensi IFRS terhadap manajemen laba, penelitian ini membuktikan bahwa adanya adopsi IFRS secara mandatory di Indonesia tidak dapat dikaitkan dengan manajemen laba yang rendah. Penelitian ini didukung oleh hasil penelitian empiris yang dilakukan Firmansyah \& Irawan (2018), penelitian ini menggunakan perusahaan manufaktur yang terdaftar di Bursa Efek Indonesia (BEI). Hasil temuan penelitian menujukkan bahwa adanya adopsi IFRS di Indonesia tidak berhasil menurunkan tindakan manajemen laba yang dilakukan oleh manajer. Dengan adanya adopsi IFRS tidak menjamin adanya penurunan tindakan manajer dalam melakukan manajemen laba.

$$
\text { Berbeda dengan penelitian }
$$
tersebut di atas, penelitian selanjutnya tentang konvergensi IFRS dan manajemen laba justru mendapatkan hasil yang bertolak berlakang yang dilakukan oleh Kurniati et al., (2021) yang menganalisis perbedaan manajemen laba sebelum dan sesudah konvergensi IFRS pada perusahaan consumer goods yang terdaftar di Bursa
Efek Indonesia (BEI).Hasilnya menunjukkan praktik manajemen laba baik sebelum dan sesudah adanya konvergensi IFRS tetap terjadi pada perusahaan consumer goods, positifnya penelitian ini menemukan bahwa setelah adanya penerapan konvergensi IFRS praktik manajemen laba menjadi menurun jika dibandingkan sebelum penerapan konvergensi IFRS. Temuan penelitian ini juga sejalan dengan penelitian yang dilakukan oleh Satria \& Jeni (2020) dan penelitian Ramadhani \& Damayanti (2018) yang melakukan penelitian mengenai perbedaan manajemen laba sebelum dan sesudah konvergensi IFRS, penelitian ini menggunakan perusahaan manufatur yang terdaftar di Bursa Efek Indonesia (BEI). Hasil penelitiannya menunjukkan bahwa perusahaan yang mengadopsi IFRS secara penuh cenderung memiliki tingkat manajemen laba yang lebih kecil jika dibandingkan sebelum pengadopsian IFRS.

Penelitian selanjutnya yang juga menyatakan bahwa dengan adanya penerapan PSAK konvergensi IFRS praktik manajemen laba semakin rendah jika dibandingkan sebelum penerapan PSAK konvergensi IFRS dilakukan olehSari (2019), penelitian ini dilakukan pada perusahaan yang termasuk dalam "50 top leadings in market capitalization" yang terdaftar di Bursa 
Efek Indonesia (BEI).Hasil penelitian menujukkan bahwa kualitas laba perusahaan "top leadings in market capitalization" yang terdaftar di Bursa Efek Indonesia (BEI) setelah adanya penerapan PSAK konvergensi IFRS meningkat atau menjadi lebih baik jika dibandingkan periode sebelum penerapan PSAK konvergensi IFRS.

Lebih frontal lagi temuan hasil penelitian yang dilakukan oleh Nastiti \& Ratmono (2015) yang menggunakan perusahaan manufatur yang terdaftar di Bursa Efek Indonesia (BEI) menyatakan bahwa konvergensi IFRS memberikan pengaruh positif terhadap manajemen laba, artinya dengan adanya penerapan IFRS justru malah meningkatkan praktik manajemen laba pada perusahaan.

Lebih lanjut mengenai temuan empiris yang membahas mengenai konvergensi IFRS dan manajemen laba disajikan pada tabel 1 .

Tabel 1

Hasil Penelitian Empiris

\begin{tabular}{|c|l|l|l|}
\hline No. & \multicolumn{1}{|c|}{ Penulis } & \multicolumn{1}{|c|}{ Judul Penelitian } & \multicolumn{1}{c|}{ Hasil Penelitian } \\
\hline 1 & $\begin{array}{l}\text { Kusumawardani, } \\
(2019)\end{array}$ & $\begin{array}{l}\text { Implikasi Manajemen Laba } \\
\text { terhadap Konvergensi IFRS } \\
\text { (International Financial } \\
\text { Reposting Standards } \text { di } \\
\text { Indonesia. }\end{array}$ & $\begin{array}{l}\text { Konvergensi IFRS tidak } \\
\text { mempengaruhi praktik } \\
\text { manajemen laba. }\end{array}$ \\
\hline 2 & $\begin{array}{l}\text { Firmansyah \& } \\
\text { Irawan, (2018) }\end{array}$ & $\begin{array}{l}\text { Adopsi IFRS, Manajemen Laba } \\
\text { Akrualdan Manajemen Riil. }\end{array}$ & $\begin{array}{l}\text { Konvergensi IFRS tidak } \\
\text { mempengaruhi praktik } \\
\text { manajemen laba. }\end{array}$ \\
\hline 3 & $\begin{array}{l}\text { Kurniati et al., } \\
(2021)\end{array}$ & $\begin{array}{l}\text { Analisis Perbedaan Manajemen } \\
\text { Laba Sebelum dan Sesudah } \\
\text { Konvergensi IFRS pada } \\
\text { Perusahaan Consumer Goods. }\end{array}$ & $\begin{array}{l}\text { Konvergensi IFRS } \\
\text { menurunkan praktik } \\
\text { manajemen laba. }\end{array}$ \\
\hline 5 & $\begin{array}{l}\text { Satria \& Jeni } \\
(2020)\end{array}$ & $\begin{array}{l}\text { Pengaruh Konvergensi IFRS } \\
\text { terhadap Manajemen Laba. }\end{array}$ & $\begin{array}{l}\text { Konvergensi IFRS } \\
\text { menurunkan praktik } \\
\text { manajemen laba. }\end{array}$ \\
\hline Ramadhani \& & $\begin{array}{l}\text { Konvergensi IFRS, Kualitas } \\
\text { Audit, dan Manajemen Laba. }\end{array}$ & $\begin{array}{l}\text { Konvergensi IFRS } \\
\text { menurunkan praktik } \\
\text { manajemen laba. }\end{array}$ \\
\hline 7 & $\begin{array}{l}\text { Namayanti (2018) } \\
\text { (2015) }\end{array}$ & $\begin{array}{l}\text { Analisis Perbedaan Manajemen } \\
\text { Laba Sebelum dan Sesudah } \\
\text { Penerapan PSAK Konvergensi } \\
\text { IFRS. }\end{array}$ & $\begin{array}{l}\text { Konvergensi IFRS } \\
\text { menurunkan praktik } \\
\text { manajemen laba. }\end{array}$ \\
\hline $\begin{array}{l}\text { Analisis Pengaruh Konvergensi } \\
\text { IFRS terhadap Manajemen Laba } \\
\text { dengan Corporate Governance } \\
\text { sebagai Variabel Moderasi. }\end{array}$ & $\begin{array}{l}\text { Konvergensi IFRS } \\
\text { meningkatkan praktik } \\
\text { manajemen laba. }\end{array}$ \\
\hline
\end{tabular}

Sumber : Penelitian Sebelumnya (diolah), 2021. 


$$
\text { Beberapa penelitian empiris }
$$
sebelumnya seperti disajikan pada tabel 1 di atasmenunjukkan bahwa terdapat perbedaan hasil penelitian yang dilakukan oleh beberapa penelitian, dari yang mulai menyatakan bahwa dengan adanya konvergensi IFRS tidak berpengaruh terhadap praktik manajemen, ada juga yang menyatakan bahwa konvergensi IFRS menurunkan praktik manajemen laba dan bahwa ada penelitian yang menyatakan bahwa dengana adanya konvergensi IFRS justru meningkatkan praktik manajemen laba. Beberapa hasil empiris tersebut menunjukkan bahwa dengan adanya konvergensi IFRS, praktik manajemen laba tetap terjadi, hal inilah yang perlu digaris bawahi dan perlu dijadikan pertimbangan kepada para pengguna laporan keuangan untuk tetap melakukan pengawasan terhadap lapo-ran keuangan perusahaan, hal ini dilakukan agar laba yang disajikan oleh perusahaan akan menyajikan informasi yang tidak menyesatkan bagi pengguna laporan keuangan dalam pengambilan keputusannya.

\section{KESIMPULAN DAN SARAN}

Penelitian ini bertujuan untuk menganalisis peluang praktik manajemen laba setelah adanya konvergensi International Financial Reporting Standarads (IFRS) di Indonesia. Berdasarkan hasil analisa di atas maka dapat disimpulkan bahwa peluang praktik manajemen laba akan ada, baik setelah adanya konvergensi IFRS, sehingga pentingnya pengawasan menurut teori agensi yang dilakukan oleh investor untuk mendapatkan informasi keuangan yang dapat diandalkan sebagai dasar pengambilan keputusan.

Analisis penelitian ini hanya berdasarkan pada literatur dari penelitian-penelitian sebelumnya, untuk memperkaya literature yang sudah ada, untuk penelitian selanjutnya disarankan untuk menggunakan data empiris dengan menggunakan objek dari berbagai jenis industry sehingga analisis mengenai konvergensi dan peluang manajemen laba menjadi lebih komprehensif.

\section{DAFTAR PUSTAKA}

Aryani, D. Septa. (2011). Manajemen Laba Pada Perusahaan Manufaktur di BursaEfek Indonesia. Jurnal Ekonomi Dan Informasi Akuntansi Vol.1 No.2 Mei2011.

Barth, M. E., Landsman, W. R., \& Lang, M. H. (2008). International accounting standards and accounting quality. Journal of Accounting Research, 46(3), 467498. https://doi.org/10.1111/j.1475679X.2008.00287.x 
Cahyati, A. D. (2011). Peluang Manajemen Laba Pasca Konvergensi Ifrs: Sebuah Tinjauan Teoritis Dan Empiris. JRAK: Jurnal Riset Akuntansi \& Komputerisasi Akuntansi, 2(01), 1-7.

https://doi.org/10.33558/jrak.v2i1. 125

Cahyonowati, N., \& Ratmono, D. (2013). Adopsi IFRS dan Relevansi Nilai Informasi Akuntansi. Jurnal Akuntansi Dan Keuangan, 14(2), 105-115. https://doi.org/10.9744/jak.14.2.10 5-115

Firmansyah, A., \& Irawan, F. (2018). Adopsi IFRS, Manajemen Laba Akrual dan Manajemen Laba Riil. Assets: Jurnal Akuntansi Dan Pendidikan, $\quad 7(2), \quad 81$. https://doi.org/10.25273/jap.v7i2.3 310

IAI. (2009),Standar Akuntansi Keuangan,Salemba empat, Jakarta.

Kartikahadi, H. (2010).Tinjauan Kritis Penerapan Standar Akuntansi Dulu Sekarang. Economic Business \& Accounting Review Vol. III no.1 April hal. 7-19

$\begin{array}{ccr}\text { Martani, Dwi. } & \text { (2014). } & \text { Dampak } \\ \text { Implementasi } & \text { IFRS } & \text { Bagi } \\ \text { Perusahaan. } & & \\ \text { hytp:/www } & & \end{array}$ http://www.academia.edu/40916 11/Dampak_Implementasi_IFRS_B AGI_PERUSAHAAN_Oleh_Dwi_Ma rtani_Staf_pengajar_Akuntansi_FE UI_anggota_tim_implementasi_IF RS

Jackson, S. B., Keune, T. M., \& Salzsieder, L. (2013). Debt, equity, and capital investment. Journal of Accounting and Economics, 56(23), 291-310. https://doi.org/10.1016/j.jacceco.20 13.09.001
Jensen, M. C., \& Meckling, W. H. (1976). Theory of Firm: Managerial Behavior, Agency Costs and Ownership Structure. Journal of Financial Economics, 3, 305-360. https://doi.org/10.1177/001872671 8812602

Kurniati, E., Dani, R., Hidayat, A., \& Siregar, N. O. (2021). Analisis Perbedaan Manajemen Laba Sebelum dan Sesudah Konvergensi IFRS Pada Perusahaan Consumer goods. Kajian Akuntansi, 22(1), 18.

Kusumawardani, M. (2019). Implikasi Manajemen Laba Terhadap Konvergensi Ifrs (International Financial Reporting Standards) Di Indonesia. AKUNTABILITAS: Jurnal Penelitian Dan Pengembangan Akuntansi, 11(2), 87-98.

https://doi.org/10.29259/ja.v11i2.8 931

Kusumawardani, N. F., \& Dewi, R. R. (2017). Motivasi Bonus, Pajak, Dan Utang Dalam Tindakan Manajemen Laba (Studi Perusahaan Manufaktur Yang Terdaftar Di Bursa Efek Indonesia Periode 2013-2015). Media Riset Akuntansi, Auditing Dan Informasi, 16(1), 79. https://doi.org/10.25105/mraai.v16 i1.2072

Lestari, Y. O. (2013). Konvergensi International Financial Reporting Standards (Ifrs) Dan Manajemen Laba Di Indonesia. El Muhasaba: Jurnal Akuntansi, 2(2). https://doi.org/10.18860/em.v2i2.2 365

Nastiti, A. D., \& Ratmono, D. (2015). Manajemen Laba dengan Corporate Governance Sebagai Variabel Moderating. Diponegoro Journal of Accounting, 4(2013), 115. 
Pamudji, S., \& Trihartati, A. (2010). Pengaruh Independensi Dan Efektivitas Komite Audit Terhadap Manajemen Laba. Jurnal Dinamika Akuntansi, 2(1), 21-29. https://doi.org/10.15294/jda.v2i1.1 924

Prima, Aditya. (2013). Ekonomi: 5 Kasus Penyimpangan Akuntansi.http://adityaprima.blog spot.com/2013/01/normal-0-falsefalse-false-in-xnonex.html

Ramadhani, F., \& Damayanti, T. W. (2018). Kualitas Audit Dan Manajemen Laba. Akutansi Bisnis \& Manajemen (ABM), 27(1), 114.

Sari, S. (2019). Analisis Perbedaan Manajemen Laba Sebelum dan Sesudah Penerapan PSAK Konvergensi IFRS. Moneter Jurnal Akuntansi Dan Keuangan, 6(1), 13-22. https://doi.org/10.31294/moneter.v $6 \mathrm{i} 1.4642$

Satria, H., \& Jeni. (2020). Pengaruh Konvergensi IFRS Terhadap Manajemen Laba. 5(2), 275-294.
Setyaningrum, S. Ika. (2008). Analisis Pengaruh Manajemen Laba (Earning Management) Terhadap Kinerja Perusahaan yang Melakukan IPO. Tesis,Universitas Sebelas Maret Surakarta.

Siregar, Sylvia Veronika. (2010), Tantangan Konvergensi IFRS-Penarapan Nilai Wajar. Economic Business \& Accounting Review Vol. III no.1 April hal.6268.

Siregar, Sylvia Veronika dan Yaniti S. Bachtiar.(2003), Hubungan antara manajemen labadengantingkat pengungkapan social. Simposium nasional akuntansi VI.
VAN DER TAS, L. G. (1992). Measuring International Harmonization and Standardization: A Comment. Abacus, 28(2), 211-216. https://doi.org/10.1111/j.1467- 6281.1992.tb00281.x

Wolk, H. I., Dodd, J. L., \& Rozycki, J. J. (2017). Accounting Theory: Conceptual Issues in a Political and Economic Environment. Accounting Theory: Conceptual Issues in a Political and Economic Environment. https://doi.org/10.4135/978150630 0108 